\title{
Evaluation of occupational genotoxic risk in a Brazilian hospital
}

\author{
Sharbel Weidner Maluf ${ }^{1,2}$ and Bernardo Erdtmann ${ }^{l}$
}

\begin{abstract}
Many therapeutic, diagnostic and prophylactic procedures used in hospitals are of potential genetic risk. An evaluation was made of genotoxic occupational risk in 42 workers from the Hospital de Clínicas de Porto Alegre, RS, Brazil, who had been occupationally exposed to lead (solder), ethylene oxide (sterilization area), antineoplastic drugs (nurses and pharmacists) or ionizing radiation. They were compared with 42 unexposed individuals. There was an increase in the frequency of binucleated cytochalasin-blocked lymphocytes with micronuclei, though it was not significant $(\mathrm{P}=0.058)$. The groups exposed to antineoplastic drugs and radiation had a significant increase in micronuclei frequency $(\mathrm{P}=0.038$ and $\mathrm{P}=0.022$, respectively). The high frequencies of dicentric bridges suggest the action of clastogenics in these two groups. These results suggest that the safety procedures adopted were very important to protect workers from exposure to mutagenic agents and should be improved in the radiological and chemotherapeutical areas.
\end{abstract}

\section{INTRODUCTION}

There is increasing concern about the mutagenic and carcinogenic effects of genotoxic agents in humans occupationally or accidentally exposed (Carrano and Natarajan, 1988). Mutagenic agents are used in hospitals either for maintenance or for the diagnosis and treatment of patients. However, for professionals who are continually exposed to these agents, the risks need to be assessed in order to establish proper management.

The mutagenic effect of ionizing radiation has been studied extensively (Fenech et al., 1990; Balasem and Ali, 1991; Erexon et al., 1991) and an increase in chromosomal aberrations was observed in occupationally exposed workers when the permissible levels of radiation were exceeded (Jha and Sharma, 1991).

Chemicals, such as cytostatic agents, induce chromosomal damage, both experimentally (in vitro) and clinically in patients (Migliore et al., 1991; Gree et al., 1991). McDiarmid et al. (1992) reported a positive correlation between the time of occupational exposure to antineoplastic drugs and the frequency of sister chromatid exchanges.

Lead disturbs cell proliferation and DNA synthesis in vivo, and may be responsible for certain types of cancer, mainly in the kidneys (Gerber et al., 1980). Lerda (1992) demonstrated that lead causes chromosomal breaks. This phenomenon, which is very frequent, is the main chromosomal alteration caused by occupational intoxication with lead.

Ethylene oxide is an alkylating agent used to sterilize hospital materials and is mutagenic in microorganisms (Pfeiffer and Dunkelberg, 1980; Agurell et al., 1991), plants (Jana and Roy, 1975), animals (Ehrenberg et al.,
1974; Generoso et al., 1980, 1983) and humans (Hogstedt et al., 1983). Workers occupationally exposed to ethylene oxide have an increased rate of chromosomal aberrations and micronucleus frequency (Ribeiro et al., 1994) and a decreased repair capacity (Mayer et al., 1991).

Workers from the Hospital de Clínicas de Porto Alegre (HCPA) were monitored using the cytokinesisblocked lymphocyte analysis (Fenech and Morley, 1985) to measure frequency of micronuclei, dicentric bridges and spindle anomalies. The main advantage of this method of evaluation is the reliable identification of cells that have completed only one nuclear division (Fenech, 1997). Our aim was to verify whether the safety procedures in use were enough to protect healthy workers from exposure to mutagenic agents.

\section{MATERIAL AND METHODS}

Peripheral blood samples were collected from 84 workers; 42 out of them were occupationally exposed to lead $(\mathrm{N}=11)$, ionizing radiation $(\mathrm{N}=11)$, ethylene oxide $(\mathrm{N}=10)$ or cytostatic drugs $(\mathrm{N}=10)$. The remaining 42 were controls from the same institution, matched for age, sex and smoking habits. The individuals exposed to lead were chosen based on their levels of delta-aminolevulinic acid and those exposed to ionizing radiation were chosen based on the level of radiation recorded by their dosimeters. The group exposed to cytostatic agents was formed by all individuals from this area and the individuals exposed to ethylene oxide were chosen based on their time of activity in the sterilization area. Table I shows the subjects' sex and age.

All individuals answered the personal health questionnaire published by the International Commission for Pro-

${ }^{1}$ Departamento de Genética, Universidade Federal do Rio Grande do Sul, Porto Alegre, RS, Brasil.

${ }^{2}$ Serviço de Genética Médica, Hospital de Clínicas de Porto Alegre, Rua Ramiro Barcelos, 2350, 90035-003 Porto Alegre, RS, Brasil. Send correspondence to S. W. M. Fax: +55-51-316-8010. E-mail: sharbel@if.ufrgs.br 
tection against Environmental Mutagens and Carcinogens (ICPEMC) (Carrano and Natarajan, 1988).

An aliquot of blood $(0.3 \mathrm{ml})$ was added to $5 \mathrm{ml}$ of standard supplemented RPMI 1640 medium containing $20 \%$ fetal calf serum and phytohemagglutinin (PHA, 0.2\%). The flasks were cultured at $37^{\circ} \mathrm{C}$. After $44 \mathrm{~h}, 4 \mu \mathrm{g}$ of cytochalasin B/ml (Sigma Chemical Co., St. Louis, MO, USA) was added (Fenech, 1993). After $72 \mathrm{~h}$, the cells were harvested and treated with sodium citrate $(1 \%)$ and then fixed in methanol:glacial acetic acid $(3: 1, \mathrm{U} / \mathrm{U})$. The slides for each individual were randomly numbered and stained with Giemsa. The presence of micronuclei and other anomalies was determined in 2000 binucleated cells per individual. The slides from exposed and non-exposed subjects were evaluated in parallel by "blind" analysis. Spindle anomalies were considered when two or more nuclei in the same cell clearly showed different sizes. The presence of dicentric bridges was scored when clearly separated nuclei were linked by nuclear material. Differences between groups were assessed using a two-sample $t$-test. The influence of age, smoking and drinking habits on the frequency of micronuclei was also examined.

\section{RESULTS AND DISCUSSION}

There was a slight non-significant increase $(\mathrm{P}=$ $0.058)$ in the frequency of micronucleated lymphocytes $(16.9 \pm 6.9)$ (in 2000 analyzed cells per individual) in exposed workers compared to the controls $(14.2 \pm 5.8)$. This slight increase in the frequency of micronuclei was attributable to those exposed to cytostatic drugs and ionizing radiation. The frequency of dicentric bridges was increased in the same groups. There was no increase in spindle disorders.

The frequency of micronucleated lymphocytes in individuals exposed to antineoplastic drugs was significantly greater $(\mathrm{P}=0.038)$ than in the paired controls. The frequency of dicentric bridges was also increased, although not significantly $(\mathrm{P}=0.0545)$, while the frequency of spindle anomalies was similar in both groups (Table II). An increased frequency of SCE has also been found, following low level exposures in nurses working with cancer patients compared to office workers (Norppa et al., 1980; Waksvik et al., 1981; Sorsa et al., 1982). Structural chromosomal aberrations were also significantly greater in nurses exposed to antineoplastic drugs compared to nonexposed laboratory workers and hospital clerks (Nikula $e t$ al., 1984). Similarly, nurses who handled cytostatic drugs without using safety covers had more dicentric chromosomes than those who used safety covers, but there was no difference in the frequency of chromosomal breaks and SCE (Oestreicer et al., 1990). Our sample consisted of nurses and pharmacists from a hospital considered to have well-established safety rules.

The group exposed to ionizing radiation had an increased frequency of micronucleated cells relative to
Table I - Age and sex of the hospital workers studied.

\begin{tabular}{|c|c|c|c|c|c|c|}
\hline \multirow[b]{3}{*}{ Group } & \multicolumn{3}{|c|}{ Exposed } & \multicolumn{3}{|c|}{ Controls } \\
\hline & \multirow{2}{*}{$\begin{array}{c}\text { Age (years) } \\
\text { mean } \pm \mathrm{SD}\end{array}$} & \multicolumn{2}{|c|}{ Sex } & \multirow{2}{*}{$\begin{array}{c}\text { Age (years) } \\
\text { mean } \pm \text { SD }\end{array}$} & \multicolumn{2}{|c|}{ Sex } \\
\hline & & M & $\mathrm{F}$ & & M & $\mathrm{F}$ \\
\hline Cytostatic drugs & $29.8 \pm 6.0$ & 1 & 9 & $28.9 \pm 4.3$ & 1 & 9 \\
\hline Lead & $38.8 \pm 7.2$ & 10 & 1 & $36.0 \pm 8.7$ & 10 & 1 \\
\hline Ethylene oxide & $35.8 \pm 6.5$ & 10 & 0 & $35.9 \pm 7.8$ & 10 & 0 \\
\hline Ionizing radiation & $40.4 \pm 7.7$ & 6 & 5 & $39.9 \pm 8.8$ & 6 & 5 \\
\hline Total & $36.4 \pm 7.8$ & 27 & 15 & $35.3 \pm 8.4$ & 27 & 15 \\
\hline
\end{tabular}

M: Male; F: female.

Table II - Frequency of binucleated lymphocytes with micronuclei (MN) and other nuclear anomalies in 2000 cells analyzed per hospital worker potentially exposed to cytostatic drugs, and their respective controls.

\begin{tabular}{|c|c|c|c|c|c|c|c|}
\hline \multicolumn{4}{|c|}{ Cytostatic drugs } & \multicolumn{4}{|c|}{ Controls } \\
\hline Subject & MN & SA & DB & Subject & MN & SA & DB \\
\hline 659 & 35 & 29 & 11 & 744 & 04 & 41 & 02 \\
\hline 692 & 30 & 83 & 06 & 555 & 17 & 64 & 03 \\
\hline 624 & 27 & 52 & 13 & 207 & 09 & 61 & 02 \\
\hline 889 & 23 & 61 & 16 & 917 & 22 & 75 & 08 \\
\hline 707 & 18 & 52 & 03 & 778 & 09 & 37 & 04 \\
\hline 013 & 18 & 35 & 04 & 015 & 10 & 43 & 03 \\
\hline 625 & 13 & 65 & 03 & 454 & 07 & 75 & 01 \\
\hline 603 & 11 & 28 & 09 & 186 & 15 & 36 & 03 \\
\hline 629 & 09 & 83 & 0 & 407 & 11 & 70 & 0 \\
\hline 014 & 08 & 50 & 01 & 713 & 11 & 39 & 01 \\
\hline Mean & $19.2^{*}$ & 53.8 & 6.6 & Mean & 11.5 & 54.1 & 2.7 \\
\hline SD & 9.3 & 19.8 & 5.4 & SD & 5.2 & 16.4 & 2.2 \\
\hline
\end{tabular}

MN - Micronuclei; SA - spindle anomalies; DB - dicentric bridges; SD standard deviation; *P $<0.05$ compared to controls.

controls $(\mathrm{P}=0.0217)$, and also a non-significantly higher frequency of dicentric bridges $(\mathrm{P}=0.1172)$. The spindle anomalies were similar in both groups (Table III). Among hospital workers, such as physicians, nurses and technicians, who are exposed to very low levels of X- or $\gamma$ rays, there is an increased frequency of chromosomal aberrations, including dicentrics (Bigatti et al., 1988). In our assay, dicentric chromosomes were indicated by the frequency of bridges. Medical workers exposed to diagnostic levels of X-rays show a higher frequency of dicentric and acentric chromosomes compared to normal controls (Jha and Sharma, 1991). The frequency of micronuclei did not show a correlation with the radiation doses recorded by the dosimeters. This result is in agreement with the results reported by Barquinero et al. (1993) in a study with 26 workers with an accumulated dose range from 2.3 to $131.7 \mathrm{mSv}$. As pointed out by Barquinero et al. (1993), it is difficult to establish doseeffect relationships for low radiation levels.

The lead-exposed group showed a similar micronuclei frequency and dicentric bridges to that of the con- 
trols (Table IV). Lead-exposed individuals had a significant increase in the frequency of spindle disorders, with no parallel increase in micronuclei frequency. Previous studies have also demonstrated a genotoxic effect of lead (Gerber et al., 1980; Lerda, 1992). Based on the low levels of aminolevulinic acid in our subjects (Table IV), there apparently was no dangerous exposure to lead in these individuals. Levels of aminolevulinic acid higher than $15 \mathrm{mg} / \mathrm{l}$ can be considered dangerous.

Although other studies have demonstrated a significant relationship between the frequency of genetic alterations and the degree of exposure to ethylene oxide (Lerda

Table III - Frequency of binucleated cells with micronuclei (MN) and other nuclear anomalies in 2000 cells analyzed per hospital worker potentially exposed to ionizing radiation, and their respective controls.

\begin{tabular}{|c|c|c|c|c|c|c|c|c|}
\hline \multicolumn{5}{|c|}{ Ionizing radiation } & \multicolumn{4}{|c|}{ Controls } \\
\hline Subject & $\mathrm{mSv}$ & $\mathrm{MN}$ & SA & $\mathrm{DB}$ & Subject & $\mathrm{MN}$ & SA & $\mathrm{DB}$ \\
\hline 166 & 2.4 & 25 & 43 & 08 & 771 & 19 & 57 & 01 \\
\hline 504 & 12.9 & 24 & 57 & 13 & 855 & 06 & 46 & 0 \\
\hline 675 & 23.6 & 23 & 33 & 04 & 426 & 15 & 43 & 08 \\
\hline 262 & 5.1 & 22 & 51 & 08 & 590 & 21 & 76 & 14 \\
\hline 557 & 2.9 & 22 & 45 & 16 & 484 & 17 & 85 & 03 \\
\hline 059 & 8.9 & 21 & 50 & 17 & 745 & 18 & 74 & 03 \\
\hline 364 & 7.4 & 21 & 67 & 0 & 126 & 17 & 43 & 10 \\
\hline 560 & 5.4 & 20 & 57 & 12 & 027 & 21 & 55 & 18 \\
\hline 755 & 4.2 & 19 & 61 & 14 & 839 & 12 & 64 & 0 \\
\hline 135 & 1.4 & 19 & 44 & 16 & 581 & 23 & 46 & 09 \\
\hline 396 & 3.6 & 14 & 72 & 0 & 548 & 05 & 56 & 0 \\
\hline Mean & 7.1 & $20.9^{*}$ & 52.7 & 10.2 & Mean & 15.8 & 58.6 & 6.0 \\
\hline SD & 6.4 & 3.0 & 11.4 & 5.7 & SD & 5.9 & 14.5 & 6.2 \\
\hline
\end{tabular}

mSv, Radiation dose in millisieverts. For other abbreviations see Table II. ${ }^{*} \mathrm{P}<0.05$ compared to controls.

Table IV - Frequency of binucleated cells with micronuclei (MN) and other nuclear anomalies in 2000 cells analyzed per hospital worker potentially exposed to lead, and their respective controls.

\begin{tabular}{|c|c|c|c|c|c|c|c|c|}
\hline \multicolumn{5}{|c|}{ Lead } & \multicolumn{4}{|c|}{ Controls } \\
\hline Subject & $\delta$-ala & $\mathrm{MN}$ & $\mathrm{SA}$ & DB & Subject & $\mathrm{MN}$ & SA & DB \\
\hline 946 & 5.5 & 24 & 81 & 03 & 242 & 06 & 69 & 05 \\
\hline 295 & 4.5 & 23 & 80 & 03 & 807 & 07 & 41 & 01 \\
\hline 282 & 5.5 & 22 & 37 & 05 & 352 & 19 & 74 & 09 \\
\hline 327 & 8.0 & 19 & 54 & 07 & 762 & 19 & 43 & 04 \\
\hline 969 & 5.0 & 17 & 74 & 07 & 538 & 06 & 73 & 03 \\
\hline 329 & 5.0 & 17 & 72 & 07 & 720 & 18 & 65 & 07 \\
\hline 162 & 4.5 & 16 & 61 & 02 & 666 & 23 & 33 & 10 \\
\hline 021 & 5.0 & 12 & 82 & 06 & 068 & 14 & 35 & 08 \\
\hline 096 & 4.5 & 11 & 60 & 08 & 360 & 23 & 40 & 11 \\
\hline 509 & 7.0 & 09 & 50 & 04 & 272 & 17 & 50 & 04 \\
\hline 637 & 4.5 & 09 & 50 & 04 & 476 & 24 & 35 & 07 \\
\hline Mean & 5.4 & 16.3 & 63.7 & 5.1 & Mean & 16.0 & 50.7 & 6.3 \\
\hline SD & 1.1 & 5.5 & 15.1 & 2.0 & SD & 6.9 & 16.3 & 3.1 \\
\hline
\end{tabular}

$\delta$-ala, Delta-aminolevulinic acid levels in urine $(\mathrm{mg} / \mathrm{l})$. For other abbreviations see Table II. and Rizzi, 1992; Ribeiro et al., 1994), we observed no such relationship (Table V), thus confirming the effectiveness of the safety procedures adopted.

There was no significant correlation between the genetic abnormalities detected and non-occupational factors such as age, sex and smoking or drinking habits, although the lack of influence of the latter on the micronuclei frequency could be related to the fact that these were not frequent habits in our subjects.

The concomitant analysis of dicentric bridges and spindle disorders when determining the micronucleus frequency does not involve much extra work, and may serve as a reference to the type of mutagen (clastogenic or aneugenic). Based on our results, we suggest clastogenic activity in the individuals with an increased frequency of micronuclei.

Workers handling antineoplastic drugs can be exposed through inhalation of aerosolis, transdermal absorption and accidental ingestion. An increase in genetic damage in workers occupationally exposed to antineoplastic drugs has been associated with careless handling (Grummt et al., 1993; Machado-Santelli et al., 1994; Sorsa and Anderson, 1996; Undeger et al., 1999). In our study, pharmacists and nurses used safety covers and followed the guidelines for working with antineoplastic drugs. Based on the results of the analysis of genetic damage by the micronuclei assay, the group of workers handling antineoplastic drugs was advised to modify their work schedule to reduce exposure time.

The safety procedures adopted were very important to protect workers from exposure to mutagenic agents and should be improved in the radiological and chemotherapeutical areas. The cytokinesis-blocked micronucleus assay appears to be useful for monitoring populations chronically exposed to genotoxic agents.

Table V - Frequency of binucleated cells with micronuclei (MN) and other nuclear anomalies in 2000 cells analyzed per hospital worker potentially exposed to ethylene oxide, and their respective controls.

\begin{tabular}{|c|c|c|c|c|c|c|c|}
\hline \multicolumn{4}{|c|}{ Ethylene oxide } & \multicolumn{4}{|c|}{ Controls } \\
\hline Subject & $\mathrm{MN}$ & $\mathrm{SA}$ & DB & Subject & $\mathrm{MN}$ & $\mathrm{SA}$ & $\mathrm{DB}$ \\
\hline 339 & 18 & 93 & 02 & 338 & 16 & 53 & 09 \\
\hline 685 & 16 & 44 & 12 & 751 & 08 & 66 & 09 \\
\hline 842 & 15 & 53 & 11 & 816 & 16 & 46 & 21 \\
\hline 113 & 11 & 46 & 04 & 160 & 10 & 54 & 08 \\
\hline 177 & 10 & 45 & 08 & 333 & 14 & 61 & 06 \\
\hline 519 & 09 & 36 & 05 & 293 & 18 & 46 & 11 \\
\hline 686 & 08 & 58 & 09 & 650 & 15 & 44 & 02 \\
\hline 841 & 08 & 50 & 07 & 448 & 08 & 35 & 04 \\
\hline 674 & 08 & 34 & 02 & 893 & 19 & 44 & 06 \\
\hline 827 & 05 & 50 & 03 & 245 & 08 & 51 & 06 \\
\hline Mean & 10.8 & 50.9 & 6.3 & Mean & 13.2 & 50.0 & 8.2 \\
\hline SD & 4.2 & 16.5 & 3.6 & SD & 4.3 & 9.0 & 5.2 \\
\hline
\end{tabular}

For abbreviations see Table II. 


\section{ACKNOWLEDGMENTS}

The authors thank the Serviço de Genética Médica, the Serviço de Segurança e Medicina do Trabalho, the physicist Alexandre Bacelar and the 84 workers who spontaneously participated in this study. This work was supported by FINEP, CNPq, FIPE-GPPG-HCPA and GENOTOX.

\section{RESUMO}

Vários procedimentos terapêuticos, diagnósticos e profiláticos usados em hospitais apresentam um risco genético. Para avaliar o risco genotóxico ocupacional, 42 trabalhadores do Hospital de Clínicas de Porto Alegre, RS, Brasil, ocupacionalmente expostos a chumbo (uso de soldas), óxido de etileno (área de esterilização), drogas antineoplásicas (enfermeiros e farmacêuticos) e radiação ionizante foram comparados com 42 indivíduos não expostos. A análise de linfócitos binucleados apresentou um aumento estatisticamente não significativo $(\mathrm{P}=0.058)$ na freqüência de micronúcleos. Quando analisados separadamente, os grupos expostos a drogas antineoplásicas e radiação ionizante apresentaram um aumento estatisticamente significativo $(\mathrm{P}=0.038 \mathrm{e} \mathrm{P}=0.0217$, respectivamente) na freqüência de micronúcleos. As frequiências de pontes dicêntricas e anomalias de fuso sugerem a ação de clastogênicos nestes dois grupos. Fatores como idade, sexo e hábitos de fumo e álcool não apresentaram correlação com as alterações genéticas observadas. Estes resultados sugerem que os procedimentos de segurança adotados foram muito importantes para proteger os trabalhadores da exposição a agentes mutagênicos e que estas medidas devem ser melhoradas nas áreas de radiologia e quimioterapia.

\section{REFERENCES}

Agurell, E., Cederberg, H., Ehrenberg, L., Lindahl-Kiessling, K., Rannug, U. and Tornqvist, M. (1991). Genotoxic effects of ethylene oxide and propylene oxide: a comparative study. Mutat. Res. 250: 229-237.

Balasem, A.N. and Ali, A.S.K. (1991). Establishment of dose-response relationships between doses of Cs137 gamma-rays and frequencies of micronuclei in human peripheral blood lymphocytes. Mutat. Res. 259: 133-138.

Barquinero, J.F., Barrios, L., Caballín, M.R., Miró, R., Ribas, M., Subias, A. and Egozcue, J. (1993). Cytogenetic analysis of lymphocytes from hospital workers occupationally exposed to low levels of ionizing radiation. Mutat. Res. 286: 275-279.

Bigatti, P., Lamerti, L., Ardito, G. and Armellino, F. (1988). Cytogenetic monitoring of hospital workers exposed to low-level ionizing radiation. Mutat. Res. 204: 343-347.

Carrano, A.V. and Natarajan, A.T. (1988). Considerations for population monitoring using cytogenetics techniques. ICPEMC publication 14. Mutat. Res. 204: 379-406.

Ehrenberg, L., Hiesche, K.D., Golkar, S.O. and Wennberg, I. (1974). Evaluation of genetic risk of alkylating agent: tissue doses in the mouse from air contaminated with ethylene oxide. Mutat. Res. 24: 83-103.

Erexon, G.L., Kligerman, A.D., Bryant, M.F., Sontag, M.R. and Halperin, E.C. (1991). Induction of micronuclei by X-radiation in human, mouse and rat peripheral blood lymphocytes. Mutat. Res. 253: 193-198.

Fenech, M. (1993). The cytokinesis micronucleus technique: a detailed description of the method and its application to genotoxicity studies in human populations. Mutat. Res. 285: 35-44.

Fenech, M. (1997). The advantages and disadvantages of the cytokinesisblock micronucleus method. Mutat. Res. 392: 11-18.

Fenech, M. and Morley, A.A. (1985). Measurement of micronuclei in lymphocytes. Mutat. Res. 147: 29-36.

Fenech, M., Denham, J., Francis, W. and Morley, A. (1990). Micronuclei in cytokinesis-blocked lymphocytes of cancer patients following fraction- ated partial-body radiotherapy. Int. J. Radiat. Biol. 57: 373-383.

Generoso, W.W., Cain, K. and Krishna, M. (1980). Heritable translocation and dominant lethal mutation induction with ethylene oxide in mice. Mutat. Res. 73: 133-142.

Generoso, W.W., Cummings, R.B., Bandy, J.A. and Cain, K. (1983). Increased dominant lethal effects due to prolonged exposure of mice to inhaled ethylene oxide. Mutat. Res. 119: 377-379.

Gerber, G.B., Léonard, A. and Jacquet, P. (1980). Toxicity, mutagenicity and teratogenicity of lead. Mutat. Res. 76: 115-141.

Gree, M.G., Zevon, M.A., Lowrie, G., Seigelstein, N. and Hall, B. (1991). Congenital anomalies in children of patients who received chemotherapy for cancer in childhood and adolescence. N. Eng. J. Med. 325: 141-146.

Grummt, T., Grummt, H.-J. and Schott, M. (1993). Chromosomal aberrations in peripheral lymphocytes of nurses and physicians handling antineoplastic drugs. Mutat. Res. 302: 19-24.

Hogstedt, C., Gullberg, B., Hednerk, K., Kolnig, A.M., Mitelman, F., Skerfving, S. and Widegreen, B. (1983). Chromosome aberrations and micronuclei in the bone marrow cells and peripheral blood lymphocytes in humans exposed to ethylene oxide. Hereditas 98: 106-113.

Jana, M.K. and Roy, K. (1975). Effectiveness and efficiency of ethyl methanesulfonate and ethylene oxide for the induction of mutation in mice. Mutat. Res. 28: 211-215.

Jha, A.N. and Sharma, T. (1991). Enhanced frequency of chromosome aberrations in workers occupationally exposed to diagnostic X-rays. Mutat. Res. 260: 343-348.

Lerda, D. (1992). The effect of lead on Allium cepa L. Mutat. Res. 281: 89-92.

Lerda, D. and Rizzi, R. (1992). Cytogenetic study of persons occupationally exposed to ethylene oxide. Mutat. Res. 281:31-37.

Machado-Santelli, G.M., Cerqueira, E.M., Oliveira, C.T. and Pereira, C.A.A.B. (1994). Biomonitoring of nurses handling antineoplastic drugs. Mutat. Res. 322: 203-208.

Mayer, J., Warburton, D., Jeffrey, A.M., Pero, R., Walles, S., Andrews, L., Toor, M., Latriano, L., Wazneh, L., Tang, D., Tsai, W.-Y., Kuroda, M. and Perera, F. (1991). Biologic markers in ethylene oxide-exposed workers and controls. Mutat. Res. 248: 163-176.

McDiarmid, M.A., Kolodner, K., Humphrey, F., Putman, D. and JacobsonKram, D. (1992). Baseline and phosphoramide mustard-induced sisterchromatid exchange in pharmacists handling anti-cancer drugs. Mutat. Res. 279: 199-204.

Migliore, L., Guidotti, P., Favre, C., Nardi, M., Sessa, M.R. and Brunori, E. (1991). Micronuclei in lymphocytes of young patients under antileukemic therapy. Mutat. Res. 263: 243-248.

Nikula, E., Kiviniitti, K., Leisti, J. and Taskinen, P.J. (1984). Chromosome aberrations in lymphocytes of nurses handling cytostatic agents. Scand. J. Work Environ. Health 10: 71-74.

Norppa, H., Sorsa, M. and Vainio, H. (1980). Increased sister chromatid exchange frequencies in lymphocytes of nurses handling cytostatic drugs. Scand. J. Work Environ. Health 67: 229-301.

Oestreicer, V., Stephan, G. and Glatzal, M. (1990). Chromosome and SCE analysis in peripheral lymphocytes of persons occupationally exposed to cytostatic drugs handled with and without the use of safety covers. Mutat. Res. 242: 271-277.

Pfeiffer, E.G. and Dunkelberg, H. (1980). Mutagenicity of ethylene oxide and propylene oxide and of the glycol and hyalohydrina formed from them during the fumigation of foodstuff. Food Cosmet. Toxicol. 18: 115-119.

Ribeiro, L.R., Salvadori, D.M.F., Rios, A.C.C., Costa, S.L., Tates, A.D., Tornqvist, M. and Natarajan, A.T. (1994). Biological monitoring of workers occupationally exposed to ethylene oxide. Mutat. Res. 313: 81-87.

Sorsa, M. and Anderson, D. (1996). Monitoring of occupational exposure to cytostatic anticancer agents. Mutat. Res. 355: 253-261.

Sorsa, M., Norppa, H. and Vainio, H. (1982). Induction of SCE among nurses handling cytostatic drugs. In: Indicators of Genotoxic Exposure (Bridges, B.A., Butterworth, B.E. and Weinstein, I.B., eds.). Cold Spring Harbor Laboratory, New York, pp. 341-350.

Undeger, I., Basaran, N., Kars, A. and Guç, D. (1999). Assessment of DNA damage in nurses handling antineoplastic drugs by the alkaline COMET assay. Mutat. Res. 439: 277-285.

Waksvik, H., Klepp, O. and Brogger, A. (1981). Chromosome analyses of nurses handling cytostatic agents. Cancer Treat. Rep. 65: 607-610. 